Available online at GSC Online Press Directory

GSC Biological and Pharmaceutical Sciences

e-ISSN: 2581-3250, CODEN (USA): GBPSC2

Journal homepage: https://www.gsconlinepress.com/journals/gscbps

(RESEARCH ARTICLE)

\title{
Methanolic extract of Caladium bicolor leaves against selected clinical isolates
}

\author{
Uche Fidelia Ijeoma ${ }^{1}$, Onuchukwu Dickson ${ }^{2}$, Ibezim Chidozie N. E. ${ }^{3}$ and Ogbu Hanson Ige ${ }^{3 *}$ \\ ${ }^{1}$ Department of Pharmacognosy, Faculty of Pharmaceutical Sciences, University Park, University of Port Harcourt, \\ Nigeria. \\ 2 Department of Pharmacognosy, Faculty of Pharmacy, Madonna University, Elele, Nigeria. \\ ${ }^{3}$ Department of Pharmaceutical Microbiology \& Biotechnology, Faculty of Pharmaceutical Sciences, University Park, \\ University of Port Harcourt, Nigeria.
}

Publication history: Received on 13 February 2019; revised on 23 February 2019; accepted on 26 February 2019

Article DOI: https://doi.org/10.30574/gscbps.2019.6.2.0022

\begin{abstract}
To survive when confronted by antibiotics, some strains of microorganisms have evolved and developed the ability to resist the most commonly prescribed forms of medication. As a result, the search for plant derived substances are now becoming one of major areas of research. Plants and their parts are valuable for food, shelter, nutraceutical and major constituent of drugs used in traditional herbal medicinal systems. Caladium bicolor leaf is used in African traditional medicine for the treatment of infections in Nigeria. In this study, the active compounds of Caladium bicolor leaf were extracted using methanol and investigated for the presence of secondary metabolites. Antimicrobial activity of the extract was determined against selected clinical isolates (Staphylococcus aureus, Escherichia coli, Proteus mirabilis, Klebsiella pneumoniae, Aspergillus fumigatus and Candida albicans) using the agar well diffusion. The methanol extract demonstrated a significant broad-spectrum antimicrobial activity against both gram-positive and gram-negative bacteria, with the highest activity having a zone of inhibition of $10 \mathrm{~mm}$. The antimicrobial activities could be attributed to the presence of phytochemicals compounds such as tannins, alkaloids, saponins. This is interesting and promising and may therefore be exploited further to understand better the mechanisms responsible for the antimicrobial activity recorded. This study can also serve as scientific bases for support of the traditional use of Caladium bicolor leaf in treatment of infections.
\end{abstract}

Keywords: Caladium bicolor; Medicinal plants; Extract; Clinical isolates; Antimicrobial activities; Phytochemicals

\section{Introduction}

The use of plants in the maintenance of good health is gaining popularity in most part of the world as the day passes by [1-3]. Many published reports have shown the effectiveness of plant-based products against resistant microorganisms [4-7]. Several of these plant-based products have found usage because of their numerous applications as food supplements, traditional medicines, modern medicines, nutraceutical, pharmaceutical intermediates and chemical activities for synthetic drugs [8]. Majority of those in developing countries are favourably disposed to the use of medicines derived from plants extract [9]. This is perhaps due to the fact that many traditional medicines are still included as part of the habitual treatment of various conditions and therefore serving as the link between communities and their surrounding vegetation [7]. Although changes in sociopolitical climate may have contributed to increased awareness of use of herbs in therapy [7]. Several other authors have also alluded to the fact that, plant-based products are affordable and possess therapeutic efficacy with significant healing power, either in their natural state or as the source of new pharmaceuticals $[1-3,6,10]$. Nevertheless, a medicinal plant is therefore, any plant in which one or more of its parts (roots, stems, barks, leaves, flowers, fruits, seeds or exudates), contain substances that can be used for therapeutic purposes or which are precursors for the synthesis of useful drugs $[2,11]$.

\footnotetext{
* Corresponding author

E-mail address: hanson.ogbu@uniport.edu.ng
}

Copyright (C) 2019 Author(s) retain the copyright of this article. This article is published under the terms of the Creative Commons Attribution Liscense 4.0. 
Plants and its products are becoming one of the bedrocks for modern medicines to attain a new principle [1-3, 6, 10]. There is currently a positive correlation between the use of plants with medicinal properties for the treatment of varieties of diseases including sexually transmitted infections, [12] fungal infections, [13] gastrointestinal nematodes, [14] tumor, fever, ulcer, convulsion, inflammation, pain, spasm [15]. At present, over 500 plants are known to be useful for medicinal purposes in Africa, but only a few have been described or studied in detail $[2,16]$. Caladium bicolor is a genus of flowering plants in the family Araceae $[17,18]$. They are known by the common name elephant ear (which they share with the closely related genera Alocasia, Colocasia and xanthosoma), Heart of Jesus and Angel wings [17]. The most distinct characteristic of the plant is the shape (lance or arrowhead), size and colour (spotted or streaked with pink, red, gray, or white) of the leaf although vary among the hundreds of selections [19]. It has injurious properties due to the presence of water-insoluble calcium oxalate raphides and unverified proteinaceous toxin constituents causing painful burning sensation of the lips and mouth upon contact $[19,20]$. The species of caladium are found in habitat described as "usually an understory tuberous herb in open areas in the forest, on creek banks, common in the areas of semi deciduous forest. Caladium is well adapted to disturbance, often proliferating in areas along roads in partial shade; ranging from near sea level to at least 1,000 $\mathrm{m}$ [21]. The wild plants grow to 15-35 inches $(40-90 \mathrm{~cm})$ tall, with leaves mostly 6-18 inches (15-45 cm) long and broad. [22]. Many parts of the plant have been used in traditional medicine to manage conditions such as convulsion in children, facial paralysis, tumours, sore throats, toothache, constipation, wounds, flu symptoms, as an antiseptic, emetic, laxative and insecticide [19].

The screening of medicinal plant extracts and plant products for antimicrobial properties show that many of such plants are primary sources of antibiotics [6,23]. Previous report indicates that microbial cells could be killed by the rupture of cell walls and membranes and by the irregular disruption of the intracellular matrix when treated with plant extracts $[4,5]$. Therefore, any substance that would act to inhibit the growth of harmful microorganisms or act to destroy them, would be of great interest [7]. The aim of this study was to evaluate the total extracts of Caladium bicolor leaf, growing at Obuno village of Igbo-Ukwu Town, Anambra State located in the South-east region of Nigeria, using methanol to establish it effectiveness against Staphylococcus aureus, Escherichia coli, Proteus mirabilis, Klebsiella pneumoniae, Aspergillus fumigatus and Candida albicans clinical isolates.

\section{Material and methods}

\subsection{Collection of plant material/identification}

Fresh leaf samples of Caladium bicolor leaf were collected at Obuno village of Igbo-Ukwu Town, Anambra State located in the South-east region of Nigeria. The plant leaf was identified and authenticated by H. Onyeachusim, a taxonomist at the Department of Pharmacognosy, Faculty of Pharmacy, Madonna University, Elele, Nigeria and voucher specimen deposited for future use at the herbarium.

\subsection{Macroscopic examination of Caladium bicolor leaf}

The leaf samples of Caladium bicolor were physically examined for their size, shape, surface, venation, petiole, apex, margin, base, texture, odour and colour as previously described [24, 25].

\subsection{Microscopic examination of Caladium bicolor leaf}

The outer epidermal membranous layers were carefully peeled off and mounted on a clean slide with the dilute glycerol after clearing with chloral hydrate, covered with a cover slip and observed under microscope. The presence or absence of epidermal cells, stomata, trichomes and cell inclusions were noted as previously described [26, 27]. A transverse section through the midrib and lamina of the freshly collected leaves were also made. The sections were mounted on slides and viewed under the microscope after being cleared with chloral hydrate [26, 27].

\subsection{Preparation of extract}

The leaf samples of Caladium bicolor were processed by washing in tap water, dried at room temperature for three weeks and placed into a blender and grounded into powder. $80.89 \mathrm{~g}$ of Caladium bicolor powder was macerated in 600 $\mathrm{ml}$ of $95 \%$ cold methanol by cold extraction for 48 hours. The mixture was filtered and concentrated to a small volume to remove all the solvent using a rotary evaporator at $40{ }^{\circ} \mathrm{C}$ as previously described [15]. 


\subsection{Moisture content/water loss on drying}

$2 \mathrm{~g}$ of leaf powder was weighed into six different clean crucibles placed in an oven at a temperature of $105^{\circ} \mathrm{C}$ for 4 hours. Allowed to cool in a desiccator and weight of the powder determined. The procedure was repeated until there was no further loss in relation to the air-dried powdered leaf and the percentage moisture content recorded as,

$$
\text { Moisture content }=\frac{W 2-W 3}{W 2-W 1} \times 100
$$

Where,

W1 = weight of container with lid;

W2 = weight of container with lid and sample before drying; and

W3 = weight of container with lid and sample after drying

\subsection{Phytochemical screening}

Tests for the screening and identification of carbohydrates, cardiac glycosides, cyanogenetic glycosides, saponins, tannins, alkaloids were carried out with the extracts using the standard procedures as described [24, 28-33]. Lignin, starch, mucilage, calcium oxalate crystals and cellulose were performed using methods previously described by Abere et al., Biswas et al. and Evans [4, 24, 26].

\subsection{Culture media}

The culture media used were Mueller Hinton Agar (MHA) for bacterial isolates and Saubouraud Dextrose Agar (SDA) for fungal isolates. The media were constituted according to manufacturer's specification, distributed accordingly to required volumes and sterilized by autoclaving at $121^{\circ} \mathrm{C}$ for $15 \mathrm{~min}$ and maintained in molten form until ready for use [34-36].

\subsection{Test organisms}

The test organisms (Staphylococcus aureus, Escherichia coli, Proteus mirabilis, Klebsiella pneumoniae, Aspergillus fumigatus and Candida albicans) were obtained from the University Port Harcourt Teaching Hospital, Port Harcourt. All isolates were sub-cultured onto selected culturing media to ensure purity and confirm their identification [15].

\subsection{Standardization of culture}

The test organisms were cultured onto selected culturing media and incubated for 18 to $24 \mathrm{~h}$ at $37{ }^{\circ} \mathrm{C}$ to obtain colonies. After overnight incubation, colonies were selected with a sterile disposable inoculating loop and transferred to a glass tube of sterile physiological saline and vortex thoroughly. The standardization of inoculums was carried out by adjusting the turbidity of each suspension to match the turbidity of $0.5 \mathrm{McFarland} \mathrm{Standards.} \mathrm{This} \mathrm{is} \mathrm{equivalent} \mathrm{to} \mathrm{approximately}$ $1.5 \times 10^{8} \mathrm{CFU} / \mathrm{mL}$ of microbial suspension, when the turbidity values of the suspensions match optically or visually. The standardized inoculum were thereafter seeded onto MHA, SDA media and allowed to set [37].

\subsection{Antimicrobial activity}

Antimicrobial susceptibility testing was done using the well-diffusion method according to the standard of the National Committee for Clinical Laboratory Standards [38]. Wells measuring $6 \mathrm{~mm}$ in diameter were aseptically bored in the MHA and SDA media using sterile cork borer. $0.2 \mathrm{ml}$ of the extract was dispensed into each well previously inoculated with the test organisms as previously reported [37]. $0.2 \mathrm{ml}$ of Ofloxacin at $50 \mu \mathrm{g} / \mathrm{ml}$ was used as positive control while organism seeded-plates without extract served as negative control. The plates were incubated at $37^{\circ} \mathrm{C}$ for 24 hours for bacterial isolates and at $25^{\circ} \mathrm{C}$ for 7 days for fungal isolates. All samples were tested in duplicate and the diameters of zones of inhibition (in millimetre) were recorded as the mean inhibition zone [4]. 


\subsection{Minimum inhibitory concentration (MIC)}

The MIC of the extract was determined by using the broth dilution technique as previously described [39]. The extract was diluted serially to produce several dilutions in decreasing order of concentration $(100,50,25,12.5,6.25,3.125$, $0.15625,0.00156,0.0000156 \mathrm{mg} / \mathrm{mL}$ ). These were then challenged with $0.1 \mathrm{~mL}$ inoculums of an overnight broth culture of the test organism. The culture was then incubated at $37^{\circ} \mathrm{C}$ for 24 hours. The lowest concentration that inhibits growth of the test organism was taken as the MIC $[39,40]$.

\section{Results and discussion}

\subsection{Macroscopy}

Results of the physical examination of (size, shape, surface, venation, petiole, apex, margin, base, texture, colour) leaf samples are shown in Table 1. The leaves are showy alternate, simple, elliptic to obovate or spatulate, larger than 1.5 $\mathrm{cm}$, venation is parallel or pinnate or palmate-netted and variegated with white, pink and red between the veins.

Table 1 Macroscopic description of Caladium bicolor Leaf

\begin{tabular}{ll}
\hline Features & Description \\
\hline Colour & Green colour with mottled red, pink and white spots \\
Condition & Fresh \\
Lamina & \\
Apex & Parallel \\
Leaf margin & Pinnate \\
Venation & Palmate-netted \\
Base & Symmetrical, Rounded \\
Composition & Simple \\
Shape & Obovate \\
Taste & Bitter \\
\hline
\end{tabular}

\subsection{Microscopy}

Microscopical features revealed that anticlinal walls are thick and straight. There are numerous uniseriate covering trichomes in both upper and lower epidermis, most of them being unicellular or multicellular. Stomata are present in both lower and upper epidermis. The stoma is surrounded by two epidermal cells whose axis is parallel to the axis of the stomata pore.

\subsection{Phytochemical screening}

Results obtained for the phytochemical screening of the leaf samples are shown in Table 2 . The analysis revealed the presence of carbohydrate, tannins, saponins, alkaloids, lignin, mucilage, cellulose, but lacking glycosides.

In this study, samples of Caladium bicolor leaf were extracted using methanol and investigated for the presence of secondary metabolites and its ability to inhibit the growth of selected clinical isolates. Phytochemical screening as earlier reported are useful in the recognition of bioactive compounds which are precursors to drug or medicine discovery and development [41]. As shown, plant extract contained the phytochemical constituents such as carbohydrate, tannins, alkaloids, saponins, lignin, mucilage, cellulose. These secondary plant metabolites are known to possess various pharmacological effects and may be responsible for the various actions of Caladium bicolor [4, 26, 4245]. Previous studies have shown the effect of saponins on infections caused by protozoans, fungi and bacteria [6]. Alinnor [46] reported on the importance of saponins as a stimulant and its role in the control of cholesterol in the body by preventing its re-absorption into the body. The combination of saponins and steroids are known to show curative activity against a number of pathogens [6]. Flavonoids and tannin containing plants are reported to be effective in the treatment of various disease conditions in the skin, mucosa, diabetes, burns, wounds, management of inflammations, 
arrest of bleeding from damaged or injured vessels by precipitating proteins to form vascular plugs [6, 46, 47]. Flavonoids and tannins compounds are described as potent biologically active compounds synthesized by plants in response to microbial infections $[48,49]$. Tannins in particular, binds to proline rich proteins, interferes with the protein synthesis and forms stable water-soluble compounds, which kills bacteria by directly damaging their cell walls [6, 50].

Table 2 Phytochemical screening

\begin{tabular}{|c|c|c|}
\hline Phytochemicals & Test & Inference \\
\hline \multirow[t]{2}{*}{ Carbohydrates } & Molisch & ++ \\
\hline & Fehling's & ++ \\
\hline \multirow{4}{*}{$\begin{array}{l}\text { Glycosides (Bontrager's test } \\
\text { for combined anthraquinone } \\
\text { glycosides) }\end{array}$} & Hydrolysis with water & --- \\
\hline & Hydrolysis with dilute acid & --- \\
\hline & Hydrolysis with dilute acid and oxidation with $\mathrm{H}_{2} \mathrm{O}_{2}$ & --- \\
\hline & Oxidative hydrolysis with ferric chloride as catalyst & --- \\
\hline \multirow[t]{2}{*}{ Cardiac Glycosides } & Keller-Killian’s & --- \\
\hline & Kadde Test & --- \\
\hline Cyanogenetic Glycosides & Cyanogenetic Glycosides & --- \\
\hline \multirow[t]{5}{*}{ Tannins } & General & +++ \\
\hline & Phenazone & +++ \\
\hline & Iron Complex & +++ \\
\hline & Formaldehyde & +++ \\
\hline & Modified Iron Complex & +++ \\
\hline Saponins & Saponins glycoside & ++ \\
\hline \multirow[t]{4}{*}{ Alkaloids } & Dragendorff's reagent & +++ \\
\hline & Wagner's reagent & +++ \\
\hline & Hager's reagent & +++ \\
\hline & Mayer's reagent & +++ \\
\hline Lignin & Lignin & ++ \\
\hline Starch & Starch & ++ \\
\hline Mucilage & Mucilage & ++ \\
\hline Calcium oxalate & Calcium oxalate & --- \\
\hline Cellulose & Cellulose & ++ \\
\hline Cutin, Suberin & Cutin, Suberin & ++ \\
\hline
\end{tabular}

\subsection{Antimicrobial screening}

The effect of the extract was assayed against six clinical isolates presented in Fig. 1 and the results showed varying degree of antimicrobial activities against the test organisms. In the antimicrobial test, Aspergillus fumigatus showed more susceptibility while $P$. mirabilis and Candida albicans displayed the most resistance to the test extracts. As shown in Table 3, the extract was tested against S. aureus, E. coli, P. mirabilis, K. pneumoniae, A. fumigatus and C. albicans and the results gave a minimum inhibition concentration value of $3.125,0.156,50,3.125,0.00156$ and $50 \mathrm{mg} / \mathrm{mL}$ respectively. The MIC helps to measure more exactly the concentration of an antimicrobial necessary to inhibit growth of standardized inoculum under defined conditions [6]. 


\section{Caladium bicolour}

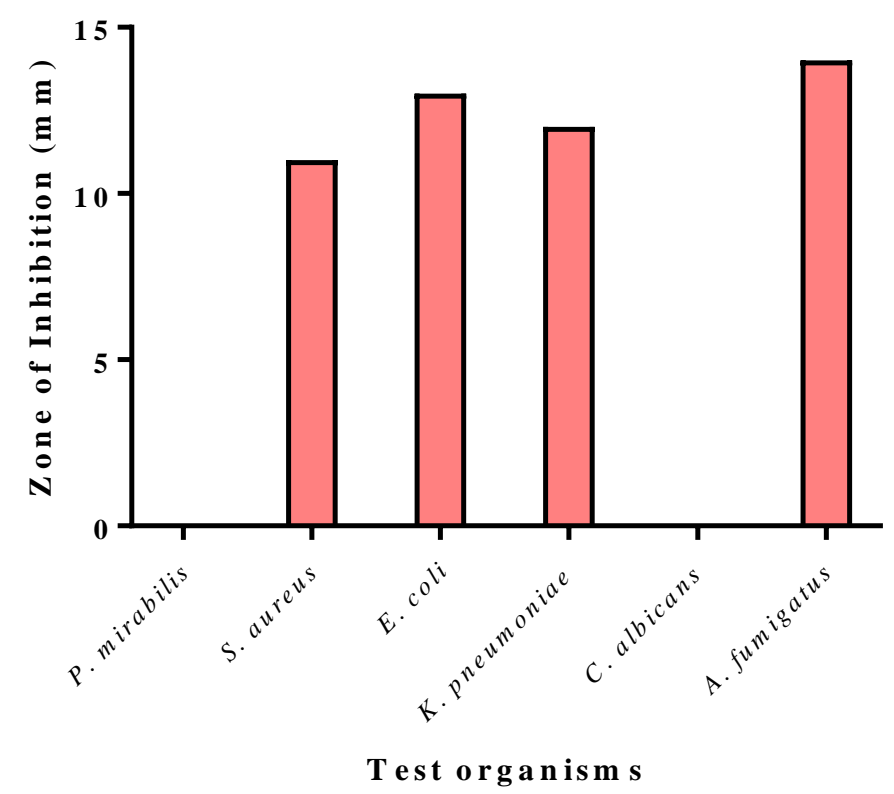

Figure 1 Inhibitory zones produced by Caladium bicolor extract against test organisms

Table 3 Inhibitory concentrations produced by Caladium bicolor extract against test organisms

\begin{tabular}{ll}
\hline Test organisms & MIC (mg/mL) \\
\hline Proteus mirabilis & 50 \\
Staphylococcus aureus & 3.125 \\
Escherichia coli & 0.156 \\
Klebsiella pneumoniae & 3.125 \\
Candida albicans & 50 \\
Aspergillus fumigatus & 0.00156 \\
\hline
\end{tabular}

The potency of plants extract is attributed to the presence of natural compounds that kills microorganisms by interfering with their digestive function [6], action of the phytochemical constituents [4, 42, 51], as they react with proteins, inhibit extracellular enzymes through hydrogen bonding, deprivation of the substrates required for microbial growth or direct action on microbial metabolism through inhibition of oxidative phosphorylation [52, 53]. The resistance of $P$. mirabilis and $C$. albicans in the present study may be due to the source of the organisms and the part of the plant studied. Previous report indicates that resistance, natural or acquired, can spread from one organism to another through vertical or horizontal exchange of genetic materials [54]. The transcriptional changes may have occurred as a result of previous exposure to sub inhibitory concentrations of antibiotics [55]. It has also been established that some species of organisms are more sensitive to chemical compounds than others due to the differences in their cell walls [20]. The findings in this study is consistent with earlier studies evaluating the phytochemical constituents of plants extracts and showing the scientific bases for it use in herbal medicine and as a source of nutrients for animals $[42,52,56]$. For example, the methanolic extract and isolated constituents of Mitracarpus scaber leaf has been reported to exhibit hepatoprotective, antibacterial and antimycotic activities [26]. Also reported is the moderate antimicrobial activity for whole plant of $C$. bicolor against S. aureus strains [57], antifungal potency of six plants of Acanthus montanus (Nees) T. Anders; Bryophyllum pinnatum Sikurz; Caladium hortulanum Vent; Commelina beghalensis (L); Sanseviera trifasciata Prain and, Zanthoxylum zanthoxyloides (Lam) Waterman extract against paddy kernel phytopathogens, in vivo and in vitro [58]. The study further supports the traditional use of whole or parts of $C$. bicolor plant extract as a 
source of compounds that contains antiangiogenic, antimicrobial, antioxidant, analgesic, anticancer, spermicidal, cytotoxic, cardiovascular and anti-allergic properties [6, 42].

\section{Conclusion}

This study has shown the phytochemicals and antimicrobial potentials of Caladium bicolor leaf extracts. Phytochemicals such as carbohydrate, tannins, alkaloids, saponins were presents. These bioactive compounds may be responsible for the various actions including the antimicrobial effects on the test organisms in vitro. Therefore, further exploitation of this plant product, for possible preparation of cheap and efficacious antibacterial therapy is hereby suggested.

\section{Compliance with ethical standards}

\section{Acknowledgments}

The authors wish to thank the Department of Pharmacognosy, Faculty of Pharmacy, Madonna University, Elele, Nigeria for the permission to use some of her facilities for this research work.

\section{Disclosure of conflict of interest}

The authors declare that the research was conducted in the absence of any commercial or financial relationships that could be construed as a potential conflict of interest.

\section{References}

[1] Moerman DE. (1996). An analysis of the food plants and drug plants of native North America. Journal of Ethnopharmacology, 52(1), 1-22.

[2] Besong EE, Balogun ME, Djobissie SFA, Obu DC and Obimma JN. (2016). Medicinal and economic value of Dialium guineense. African Journal of Biomedical Research, 19, 163-170.

[3] Edeoga HO and Eriata DO (2001). Alkaloid, tannin and saponin components of some Nigerian medicinal plants. Journal of Medicinal and Aromatic plant science, 23, 244-249.

[4] Biswas B, Rogers K, McLaughlin F, Daniels D and Yadav A. (2013). Antimicrobial activities of leaf extracts of guava (Psidium guajava L.) on two gram-negative and gram-positive bacteria. International Journal of Microbiology, vol. 2013, Article ID 746165, 1-7.

[5] Kim S and Fung DYC. (2004). Antibacterial effect of crude water-soluble arrowroot (Puerariae radix) tea extracts on food-borne pathogens in liquid medium. Letters in Applied Microbiology, 39(4), 319-325.

[6] Alorkpa EJ, Boadi NO, Badu M and Saah SA. (2016). Phytochemical screening, antimicrobial and antioxidant properties of assorted Carica papaya leaves in Ghana. Journal of Medicinal Plants Studies, 4(6), 193-198.

[7] Koleosho AT, Jose AR, Oyibo PG, Roland-Ayodele MA and Uloko ME. (2013). Antimicrobial activity of Sphenocentrum jollyanum and mangifera indica linn on Salmonella typhi. IOSR Journal of Pharmacy and Biological Sciences, 5(3), 50-54.

[8] Ncube NS, Afolayan AJ and Okoh AI. (2008). Assessment techniques of antimicrobial properties of natural compounds of plant origin: current methods and future trends. African Journal of Biotechnology, 7(12), 1797 1806.

[9] WHO. (2002). Traditional medicine: Growing needs and potential. WHO policy prospectives on medicines. World Health Organization. In. Geneva; 1-6.

[10] Kamba AS and Hassan LG. (2010). Phytochemical screening and antimicrobial activities of Euphorbia balsamifera leaves, stems and root against some pathogenic microorganisms. African Journal of Pharmacy and Pharmacology, 4(9), 645-652.

[11] Abolaji O, Adebayo A and Odesanmi O. (2007). Nutritional qualities of three medicinal plant parts (Xylopia aethiopica, Blighia sapida and Parinari polyandra) commonly used by pregnant women in the western part of Nigeria. Pakistan Journal of Nutrition, 6(6), 665-668. 
[12] De Wet H, Nzama VN and Van Vuuren SF. (2012). Medicinal plants used for the treatment of sexually transmitted infections by lay people in northern Maputaland, KwaZulu-Natal Province, South Africa. South African Journal of Botany, 78, 12-20.

[13] Runyoro DKB, Ngassapa OD, Matee MIN, Joseph CC and Moshi MJ. (2006). Medicinal plants used by Tanzanian traditional healers in the management of Candida infections. Journal of Ethnopharmacology, 106(2), 158-165.

[14] Qadir S, Dixit A and Dixit P. (2010). Use of medicinal plants to control Haemonchus contortus infection in small ruminants. Veterinary World, 3(11), 515-518.

[15] Arullappan S, Zakaria Z and Basri DF. (2009). Preliminary Screening Of Antibacterial Activity Using Crude Extracts Of Hibiscus Rosa Sinensis. Tropical Life Sciences Research, 20(2), 109-118.

[16] Taylor JLS, Rabe T, McGaw LJ, Jäger AK and van Staden J. (2001). Towards the scientific validation of traditional medicinal plants. Plant Growth Regulation, 34(1), 23-37.

[17] Hussain R, Younis A, Riaz A, Tariq U, Ali S, Ali A and Raza S. (2017). Evaluating sustainable and environment friendly substrates for quality production of potted Caladium. International Journal of Recycling of Organic Waste in Agriculture, 6(1), 13-21.

[18] Deng Z. (2012). Caladium Genetics and Breeding: Recent advances. Floriculture and Ornamental Biotechnology, 6(1), 53-61.

[19] Tosoc JPS, Frediles VCP, Canda C and Demayo CG. (2016). Antiangiogenic, antitoxic and antioxidant properties of methanolic extracts of Caladium bicolor (Aiton) Venten. HVM Bioflux, 8(1), 10-16.

[20] Essien EE, Jacob IE and Thomas PS. (2015). Phytochemical Composition, Antimicrobial and Antioxidant Activities of Leaves and Tubers of Three Caladium Species. International Journal of Medicinal Plants and Natural Products, 1(2), 24-30.

[21] Croat TB. (1994). Taxonomic Status of Neotropical Araceae vol. 74. USA.

[22] Funk VA, Berry PE, Alexander S, Hollowell TH and Kelloff CL. (2007). Checklist of the Plants of the Guiana Shield (Venezuela: Amazonas, Bolivar, Delta Amacuro; Guyana, Surinam, French Guiana). Contributions from the United States National Herbarium, 55, 1-584.

[23] Suresh K, Deepa P, Harisaranraj R and Vaira AV. (2008). Antimicrobial and phytochemical investigation of the leaves of Carica papaya L, Cynodon dactylon (L.) Pers, Euphorbia hirta L, Melia azedarach. L and Psidium guajava L. Ethnobotanical Leaflets, 12, 1184-1191.

[24] Evans WC and Evans D. (2002). Trease and Evans Pharmacognosy: W.B. Saunders.

[25] Wallis T. (1985). Textbook of Pharmacognosy.

[26] Abere TA, Onwukaeme DN and Eboka CJ. (2007). Pharmacognostic evaluation of the leaves of Mitracarpus scaber Zucc (Rubiaceae), vol. 6.

[27] Pharmacopoeia A. (1986). General methods for Analysis. OAU / STRC Scientific Publications, 2(2):1 - 5, 137 149, 223 - 237.

[28] Nana FW, Hilou A, Millogo JF and Nacoulma OG. (2012). Phytochemical Composition, Antioxidant and Xanthine Oxidase Inhibitory Activities of Amaranthus cruentus L. and Amaranthus hybridus L. Extracts. Pharmaceuticals.

[29] Evans WC and Evans D. (2009). Chapter 17 - General methods associated with the phytochemical investigation of herbal products. In: Trease and Evans' Pharmacognosy (Sixteenth Edition). W.B. Saunders, 135-147.

[30] Brain KR and Turner TD. (1975). The practical evaluation of phytopharmaceuticals. Bristol: WrightScientechnica.

[31] Ciulei I. (1982). Practical manuals on the industrial utilization of medicinal and aromatic plants. 1, 1. Bucarest (Faculty of pharmacy).

[32] Harborne AJ. (1998). Phytochemical Methods A Guide to Modern Techniques of Plant Analysis: Springer Netherlands.

[33] Sofowora A. (2009). Chapter 38 - Plants in African traditional medicine some perspectives. In: Trease and Evans' Pharmacognosy (Sixteenth Edition). W.B. Saunders, 511-520.

[34] Sandle T. (2016). Microbiological culture media. In: Pharmaceutical Microbiology. Oxford: Woodhead Publishing, 47-61. 
[35] Cundell AM. (2002). Review of the media selection and incubation conditions for the compendial sterility and microbial limit tests, vol. 28.

[36] Institute CLS. (2009). Performance Standards for Antimicrobial Susceptibility Testing, Nineteenth informational supplement M100-S19, Wayne, Pa, USA. Clinical and Laboratories Standards Institute.

[37] Olajubu F, Akpan I, Ojo D and Oluwalana S. (2012). Antimicrobial potential of Dialium guineense (Wild) stem bark on some clinical isolates in Nigeria. International Journal of Applied and Basic Medical Research, 2(1), 58-62.

[38] Stamdards A. (2010). Performance standards for antimicrobial susceptibility testing. Approved Standards CLSI, M100-S120.

[39] Okore V. (2009). Principles of Pharmaceutical Microbiology, 2nd edn. Enugu, Nigeria: EphrataPublishers.

[40] Ogbu H and Momodu I. (2018). Comparative Assay of Ciprofloxacin and Doxycycline Brands Marketed in Port Harcourt Metropolis Nigeria against Staphylococcus aureus Clinical Isolate. European Journal of Pharmaceutical and Medicinal Research, 5(11), 146-153.

[41] Jaafar NS, Hamad MN, Alshammaa DA and Abd MR. (2018). Preliminary Phytochemical Screenig and High Performance Thin Layer Chromatography [HPTLC] Detection of Phenolic Acids in Lanata Camara Leaves Cultivated in Iraq International Research Journal of Pharmacy, 9(7), 59-64.

[42] Ijoma KI and Ajiwe VIE. (2017). Phytochemical Screening of Dialium Indum Leaf extract (Velvet Tarmarind). International Journal of Phytopharmacy, 7(1), 06-13.

[43] Ulubelen A. (2003). Cardioactive and antibacterial terpenoids from some Salvia species. Phytochemistry, 64(2), 395-399.

[44] Akiyama H, Fujii K, Yamasaki O, Oono T and Iwatsuki K. (2001). Antibacterial action of several tannins against Staphylococcus aureus. Journal of Antimicrobial Chemotherapy, 48(4), 487-491.

[45] Min BR, Pinchak WE, Merkel R, Walker S, Tomita G and Anderson RC. (2008). Comparative antimicrobial activity of tannin extracts from perennial plants on mastitis pathogens. Scientific Research and Essays, 3(2), $066-073$.

[46] Alinnor IJ. (2007). Preliminary Pytochemical and antibacterial activity screening of seeds of Garcinia Cola. Journal of Chemical Society of Nigeria, 32(2), 41-47.

[47] Penecilla GL and Magno CP. (2011). Antibacterial activity of extracts of twelve common medicinal plants from Philippines. Journal of Medicinal Plants Research, 5(16), 3975-3981.

[48] Sofowora A. (1993). Medicinal Plants and Traditional Medicine in Africa, 2nd edn. Ibadan, Nigeria: Spectrum Books.

[49] Cowan MM. (1999). Plant products as antimicrobial agents. Clinical Microbiology Reviews, 12(4), 564-582.

[50] Shimada T. (2006). Salivary Proteins as a Defense Against Dietary Tannins. Journal of Chemical Ecology, 32(6), 1149-1163.

[51] Balandrin MF, Klocke JA, Wurtele ES and Bollinger WH. (1985). Natural plant chemicals: sources of industrial and medicinal materials. Science, 228(4704), 1154.

[52] David AA, Olaniyi AT, Mayowa AO, Olayinka AA and Anthony OI. (2011). Anti-Vibrio and preliminary phytochemical characteristics of crude methanolic extracts of the leaves of Dialium guineense (Wild). Journal of Medicinal Plants Research, 5(11), 2398-2404.

[53] Scalbert A. (1991). Antimicrobial properties of tannins. Phytochemistry, 30(12), 3875-3883.

[54] Ibezim CNE, Chukwuekem OC and Ogbu HI. (2018). Quality Assessment of Some Antacid Suspensions Marketed in Port Harcourt Metropolis, South-South Nigeria World Journal of Pharmaceutical and Life Sciences, 4(11), 216221.

[55] Mesak LR, Miao V and Davies J. (2008). Effects of Subinhibitory Concentrations of Antibiotics on SOS and DNA Repair Gene Expression in Staphylococcus aureus. Antimicrobial agents and chemotherapy, 52(9), 3394.

[56] Ogu GI, Ezeadila J and Ehiobu JM. (2013). Antioxidant and antimicrobial activities of Dialium guineense (Willd) leaf extract. Pharmacy and Pharmacology Research, 1(1), 1-7.

[57] Biswas MK, Mridha SA, Rashid MA and Sharmin T. (2013). Membrane Stabilizing and Antimicrobial Activities of Caladium Bicolor and Chenopodium Album. IOSR Journal of Pharmacy and Biological Sciences, 6(5), $62-65$. 
Uche et al. / GSC Biological and Pharmaceutical Sciences 2019, 06(02), 098-107

[58] Obi VI. (2012). Activity of botanical extracts on paddy rice pathogen. American-Eurasian Journal of Sustainable Agriculture, 6(2), 66-73.

\section{How to cite this article}

Uche FI, Onuchukwu D, Ibezim CNE and Ogbu HI. (2019). Methanolic extract of Caladium bicolor leaves against selected clinical isolates. GSC Biological and Pharmaceutical Sciences, 6(2), 98-107. 